\title{
29. SEDIMENT SLUMPS IN THE MIDDLE AND LOWER EOCENE OF DEEP SEA DRILLING PROJECT HOLES 605 AND 613: CHEMICAL DETECTION BY PYROLYSIS TECHNIQUES1
}

\author{
Martha E. Tarafa and Jean K. Whelan, Woods Hole Oceanographic Institution \\ and \\ Gregory S. Mountain, Lamont-Doherty Geological Observatory²
}

\begin{abstract}
Twenty-four sediment samples from DSDP Holes 605 (Leg 93) and 613 (Leg 95) on the New Jersey continental rise were analyzed by pyrolysis-gas chromatography. Twelve of these samples were also analyzed by pyrolysis-gas chromatography/mass spectrometry. The degree of preservation of sediment organic matter, as determined by these techniques, helped to distinguish slumped sediments from sediments that have not moved from their original place of deposition. Total levels of pyrolyzable organic material, as determined from pyrolysis-gas chromatography, were low in sediments that were not slumped, indicating that the organic material is highly degraded. Nitrogen- and oxygen-containing compounds were the primary compounds detected by gas chromatography/mass spectrometry (GCMS) analysis of the pyrolyzate of non-slumped sediments. Smaller amounts of aromatic compounds and branched alkanes were also present in some of these samples. In contrast, slumped sediments showed larger amounts of pyrolyzable organic matter, as determined from pyrolysis-gas chromatography, and better preservation of alkyl chains in the sediment organic matter, as suggested by the presence of $n$-alkanes in GCMS analysis of the pyrolyzate. Better preservation of the organic matter in slumped sediments can be attributed to more moderate bioturbation by bottom-dwelling organisms at the original deposition site.
\end{abstract}

\section{INTRODUCTION}

Holes 605 and 613 were drilled in the North American Basin during Legs 93 and 95 of the Deep Sea Drilling Project as part of a transect across the New Jersey continental shelf, slope, and rise. The adjacent Baltimore Canyon Trough is one of the world's most studied sedimentary basins and is covered by an extensive grid of seismic-reflection lines. Among these is U.S.G.S. seismic Line 25 , which begins on the inner continental shelf 20 $\mathrm{km}$ off Atlantic City and continues to the middle continental rise. Site 605 is located $0.4 \mathrm{~km}$ southwest of shot point 3380 of Line 25 . Site 613 is $6 \mathrm{~km}$ northeast of shot point 3470 , and is located near shot point 1460 of Line 35 (Fig. 1).

Reflectors within middle and lower Eocene sediments can be traced along Line 25 from the edge of the continental shelf to these two drill sites (Fig. 1). What begin as high-amplitude, continuous, parallel reflectors on the shelf and upper rise become weak, erratic, steeply dipping reflectors at the base of the slope. These latter seismic characteristics, indicative of sediment displaced downslope by slumping, were confirmed during visual examination of cores recovered during DSDP Legs 93 and 95 (Poag and Mountain, this volume).

Sediment samples selected for this study from the middle and lower Eocene were described as "slumped" or "non-slumped" by visual examination of the cores during shore-based subsampling. "Slumped" refers to a sed-

\footnotetext{
${ }^{1}$ Poag, C. W., Watts, A. B., et al., Init. Repts. DSDP, 95: Washington (U.S. Govt. Printing Office).

2 Addresses: (Tarafa, Whelan) Chemistry Department, Woods Hole Oceanographic Institution, Woods Hole, MA 02543; (Mountain) Lamont-Doherty Geological Observatory, Palisades, NY 10964.
}

iment mass that became detached from its location of original deposition and slid downslope as one or more intact units. Despite various degrees of distortion, original bedding planes are recognizable. Single slump units are from a few centimeters to more than a meter thick and exhibit folded bedding planes, indicating that the sediment was soft when it was displaced. Sample intervals, sub-bottom depth, geologic age, percent organic carbon content, and visual descriptions of some of the samples as "slumped" or "non-slumped" are summarized in Tables 1 and 2 for Holes 605 and 613, respectively; "uncertain" in those tables refers to samples that cannot be identified with certainty as slumps or nonslumps from visual examination of the cores.

The middle Eocene sediments collected at both Hole 605 and Hole 613 are siliceous nannofossil chalks. In the lower Eocene sediments at both sites, some of the biogenic silica has been partly dissolved and reprecipitated as opal CT. The resulting rocks are porcellanitic nannofossil chalk and limestone. All Eocene strata are light greenish gray to light gray and intensely burrowed at all depths, except in slumped intervals, in which bioturbation is moderate. Average sediment accumulation rates at both sites were between 3 and $6 \mathrm{~cm} / \mathrm{k}$.y. (Site 613 chapter, this volume).

Pyrolysis techniques were chosen for study of these samples because previous studies, including studies of DSDP sediments, have shown that differences or similarities in the composition of organic matter in sediments can be distinguished by pyrolysis. It has been observed that the "pattern" of peaks obtained from gas chromatography (GC) of pyrolysis products (P2) is similar for samples containing organic matter of similar compositions; likewise, patterns are dissimilar among samples in which the composition of organic matter varies because 


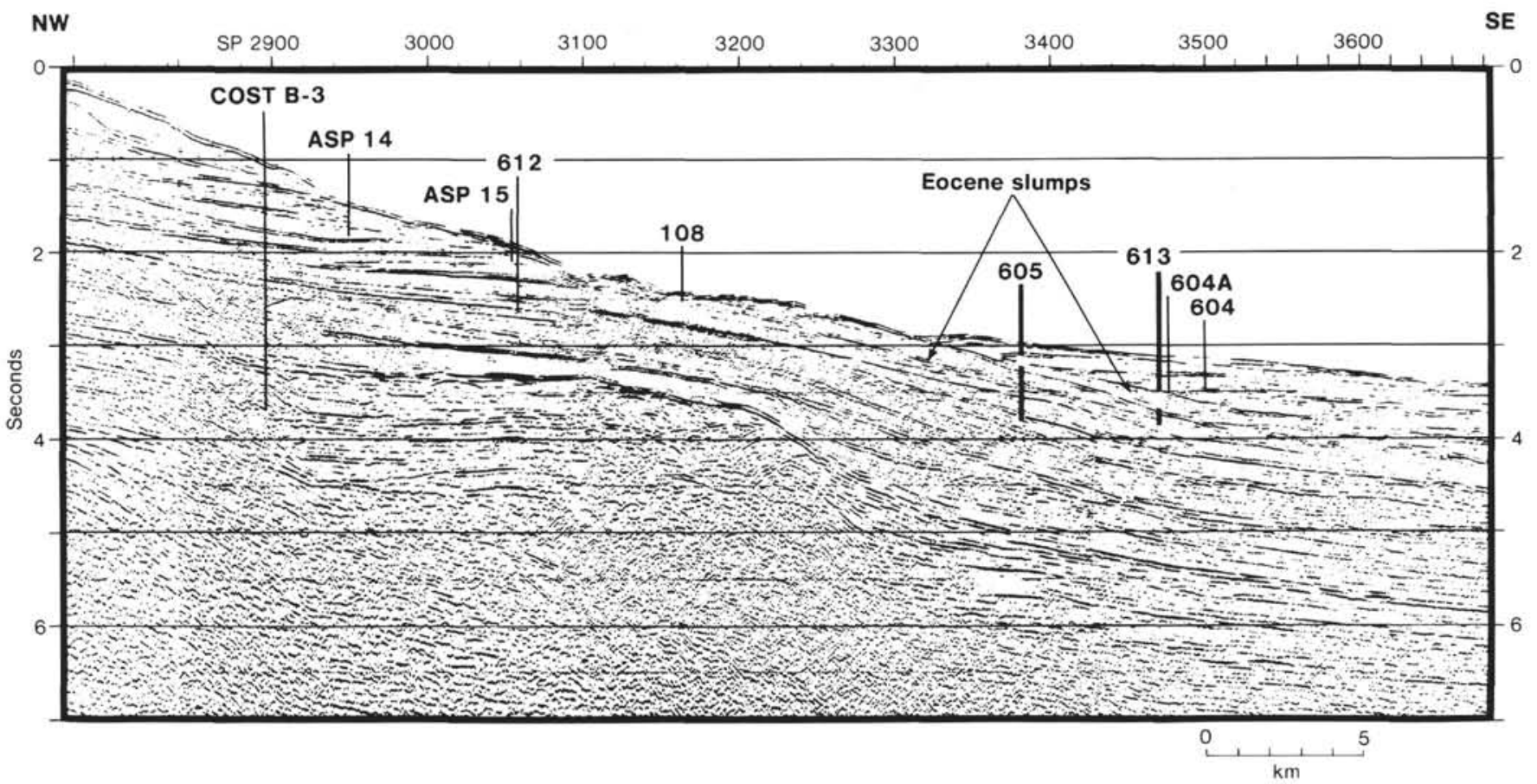

Figure 1. Projection of DSDP sites on USGS seismic Line 25. Sites 605 and 613 are the DSDP sites referred to in this study. Gaps in vertical lines representing projected core sites indicate this depositional unit not sampled at the actual site.

Table 1. Samples analyzed from DSDP Hole 605.

\begin{tabular}{lcccc}
\hline $\begin{array}{c}\text { Core-Section, } \\
\text { interval } \\
(\mathrm{cm})\end{array}$ & $\begin{array}{c}\text { Sub-bottom } \\
\text { depth } \\
(\mathrm{m})\end{array}$ & $\begin{array}{c}\text { Organic } \\
\text { carbon } \\
(\%)\end{array}$ & Age & $\begin{array}{c}\text { Deposition } \\
\text { (from visual } \\
\text { examination } \\
\text { of cores) }\end{array}$ \\
\hline $10-3,7-10$ & 234.17 & 0.41 & middle Eocene & Uncertain \\
$11-3,43-46$ & 244.13 & 0.41 & middle Eocene & Uncertain \\
$24-3,114-117$ & 369.64 & 0.34 & early Eocene & Uncertain \\
$26-4,115-118$ & 390.35 & 0.43 & early Eocene & Uncertain \\
$26-5,118-121$ & 391.88 & 0.47 & early Eocene & Slumped \\
$26-6,88-91$ & 393.08 & 0.34 & early Eocene & Slumped \\
$27-1,10-13$ & 394.40 & 0.28 & early Eocene & Uncertain \\
$29-5,79-82$ & 420.29 & 0.31 & early Eocene & Non-slumped \\
$31-3,80-83$ & 436.50 & 0.31 & early Eocene & Non-slumped \\
$33-3,133-136$ & 456.23 & 0.40 & early Eocene & Uncertain \\
$35-3,78-31$ & 474.88 & 0.28 & early Eocene & Non-slumped \\
\hline
\end{tabular}

Table 2. Samples analyzed from DSDP Hole 613.

\begin{tabular}{lcccc}
\hline $\begin{array}{c}\text { Core-Section, } \\
\text { interval } \\
(\mathrm{cm})\end{array}$ & $\begin{array}{c}\text { Sub-bottom } \\
\text { depth } \\
(\mathrm{m})\end{array}$ & $\begin{array}{c}\text { Organic } \\
\text { carbon } \\
(\%)\end{array}$ & Age & $\begin{array}{c}\text { Deposition } \\
\text { (from visual } \\
\text { examination } \\
\text { of cores) }\end{array}$ \\
\hline $28-3,70-73$ & 349.50 & 0.28 & middle Eocene & Uncertain \\
$29-5,83-85$ & 362.23 & 0.45 & middle Eocene & Uncertain \\
$31-3,65-68$ & 377.65 & 0.42 & middle Eocene & Uncertain \\
$36-2,93-96$ & 423.43 & 0.44 & middle Eocene & Uncertain \\
$36-3,33-36$ & 424.33 & 0.40 & middle Eocene & Non-slumped \\
$36-4,70-73$ & 426.20 & 0.46 & middle Eocene & Uncertain \\
$37-2,77-80$ & 432.77 & 0.33 & middle Eocene & Slumped \\
$37-4,118-121$ & 436.18 & 0.50 & early Eocene & Slumped \\
$39-3,119-122$ & 453.69 & 0.35 & early Eocene & Slumped \\
$43-3,68-71$ & 490.78 & 0.43 & early Eocene & Non-slumped \\
$44-3,117-120$ & 500.57 & 0.28 & early Eocene & Slumped \\
$50-3,87-90$ & 557.27 & 0.24 & early Eocene & Non-slumped \\
$52-3,102-105$ & 576.42 & 0.26 & early Eocene & Non-slumped \\
\hline
\end{tabular}

of different sources (marine, terrestrial, or bacterial) or different diagenetic histories (Huc et al., 1981; Whelan and Hunt, 1983; Jasper et al., 1984). Pyrolysis-gas chromatography and pyrolysis-gas chromatography/mass spectrometery (GCMS) were used in this study to determine whether pyrolysis techniques could be used to distinguish the composition of organic matter in slumped sediments from that of organic matter in non-slumped sediments.

\section{PROCEDURES}

All 24 sediment samples were analyzed by pyrolysis-GC to compare quantitatively the amount of total pyrolyzable organic matter in the sediments. Pyrolysis-GCMS was then carried out on 12 of the samples to obtain a qualitative description of the class and general structure of compounds evolved from pyrolysis.

The pyrolysis technique used was that previously described in detail by Whelan and Hunt (1983), with the following modifications: (1) a Chemical Data System (CDS) desorber probe was used instead of the previously described platinum pyrolysis coil probe; and (2) the OV101 capillary GC column in the system was replaced with a J\&W DB-5 (methylphenylsilicone) $50-\mathrm{m} \times 0.32-\mathrm{mm}$ ID fused-silica capillary GC column programmed from 40 to $250^{\circ} \mathrm{C}$ at $4^{\circ} / \mathrm{min}$.

Whole, wet, ground sediment samples were pyrolyzed in a CDS 820 Reaction System. Samples ( 40 to $60 \mathrm{mg}$ ) were weighed into quartz glass tubes $(1.8 \mathrm{~cm} \times 3.0 \mathrm{~mm}$ ID) and placed in a CDS desorber probe. The probe containing the sample was placed in the cooled interface of the 820 Reaction System. The interface was heated to $250^{\circ} \mathrm{C}$ after the probe was inserted. Volatile $C_{1}$ to $C_{25}$ organic compounds (which are minimal in these sediments and therefore were not analyzed) were desorbed from the sample at $250^{\circ} \mathrm{C}$. These were vented out of the interface so that they would not interfere with the collection of pyrolysis products. After the volatile hydrocarbons had been removed from the sample, the sample was further heated from 250 to $550^{\circ} \mathrm{C}$ at $30^{\circ} \mathrm{C} / \mathrm{min}$. This heating from 250 to $550^{\circ} \mathrm{C}$, resulting in the breakdown of material of higher molecular weight (Whelan and Hunt, 1983), is referred to as "pyrolysis." Helium carrier gas swept the compounds generated from pyrolysis away from the sample. The gas stream was divided via a three-way splitter, and portions of the sample were sent to (1) a flame-ionization detector (FID), (2) a Tenax trap, which can be 
desorbed to an on-line gas chromatograph, and (3) a small stainless steel trap $(9 \mathrm{~cm} \times 2 \mathrm{~mm}$ OD) filled with Tenax to trap material for GCMS analysis (mass spectrometer traps). A clean trap, which had been baked overnight in a helium stream at $250^{\circ} \mathrm{C}$, was placed in the CDS Reaction System before pyrolysis of the sample. After the sediment pyrolysis was completed, the MS trap was removed, sealed under nitrogen in a glass ampoule, and frozen for subsequent GCMS analysis to elucidate the composition of the large number of compounds usually generated from sediment pyrolysis.

GCMS analysis was carried out by thermally desorbing the compounds in the MS traps into a Finnigan 4500 quadrupole mass spectrometer. The MS traps were desorbed for $20 \mathrm{~min}$. in a helium gas stream via a heated desorption module attached to the injection port of the GCMS system. Compounds were swept to a Carlo Erba 4160 GC coupled to the system. During desorption, the GC oven was held at $-20^{\circ} \mathrm{C}$. Compounds were separated by a J\&W DB-5 (methylphenyl-silicone) $30-\mathrm{m} \times 0.32-\mathrm{mm}$ ID fused silica capillary column programmed from 40 to $280^{\circ} \mathrm{C}$ at $4^{\circ} \mathrm{C} / \mathrm{min}$. Spectra were acquired using electron-impact ionization at $70 \mathrm{eV}$ and were collected scanning from 40 to $350 \mathrm{amu}$ at 1-s intervals. The GCMS system was interfaced to a Finnigan Incos 2300 Data System, which contains the NBS/EPA/NIH reference library of spectra $(31,000$ spectra). Compounds were identified using the forward-search algorithm included with the Incos system. This type of identification is useful in determining the general types of compounds present. Further work with authentic standards is in progress to confirm these preliminary identifications.

Percent organic carbon was determined by combustion on ground, dried, decarbonated (by $\mathrm{HCl}$ vapor) sediment samples, using a LECO analyzer (Jasper et al., 1984).

\section{RESULTS AND DISCUSSION}

\section{Pyrolysis-GCMS}

Pyrolysis-GCMS was used in this study to investigate qualitative differences that may exist between the composition of organic matter in slumped sediments and that of organic matter in non-slumped sediments. Table 3 summarizes the compounds found in GCMS analysis of the pyrolyzate of individual samples. Compounds are grouped into oxygen-containing compounds, nitrogencontaining compounds, and hydrocarbons. Compounds that produce more dominant peaks in the chromatogram are marked by an asterisk (*) in Table 3. "Dominant" peaks $\left({ }^{*}\right)$ are peaks that have at least twice the relative intensity of the remainder of the peaks in the chromatogram. Even though a more sophisticated method of looking at this "visual" criterion is essential, we think that qualitative comparison of the chromatograms provides an adequate first look at the data. This visual comparison is explained in the following discussion of Figures $2 \mathrm{~A}, 2 \mathrm{~B}$, and $2 \mathrm{C}$.

Figure 2A (Sample 613-43-3, 69-71 cm) is a reconstructed ion chromatogram (RIC) obtained by GCMS analysis of a sample from an interval visually evaluated as non-slumped sediment (Table 2). A RIC is a total ion trace obtained from GCMS, and is qualitatively equivalent to the trace obtained by FID-GC. Note in Figure 2A that few peaks are present in the chromatogram, in contrast to Figure $2 \mathrm{C}$. Heptadecane $\left(n \mathrm{C}_{17}\right)$ is present in Figure $2 \mathrm{~A}$, but the peak corresponding to this compound is small. Figure 2B (Sample 613-37-2, 77-80 cm) is a RIC of a sample from an interval visually evaluated as a slump (Table 2). Note that although very few peaks are present in this chromatogram, the heptadecane peak is more than two times as high as the rest of the peaks in the chromatogram. With respect to the number of $n$-al- kane hydrocarbon peaks, Figure 2B is the "weakest" chromatogram obtained for the samples described as being from slumps, since only heptadecane is present in this sample. Figure 2C (Sample 613-44-3, 117-120 cm) is a more typical RIC of a slumped sediment. Pentadecane $\left(n \mathrm{C}_{15}\right)$, hexadecane $\left(n \mathrm{C}_{16}\right)$, and heptadecane are dominant in this sample. Tetradecane $\left(n \mathrm{C}_{14}\right)$ is also present in this sample.

Table 3 shows that oxygen- and nitrogen-containing compounds are present in all the samples analyzed. It has been shown that, for colloidal organic matter, pyrolysis of the carbohydrate fraction yields primarily oxygen-containing compounds, and that nitrogen-containing compounds are derived primarily from the pyrolysis of the protein fraction (Sigleo et al., 1982). Oxygen- and nitrogen-containing compounds in the pyrolyzate of the DSDP sediment samples analyzed in this study may be derived from residual carbohydrate and protein constituents of the sediment organic matter.

The hydrocarbon fraction of the pyrolyzate (Table 3 and Figs. 2A to 2C) shows some characteristics that distinguish between the samples. The outstanding difference between samples is the presence or absence of dominant normal-alkane ( $n$-alkane) hydrocarbons. The occurrence of predominant $n$-alkane peaks in the pyrolyzate appears to be related to the depositional history of the samples, as described in Tables 1 and 2, that is, whether the sediment is slumped (more alkanes) or nonslumped (less alkanes).

Several or dominant $n$-alkanes occur, for example, in sediment Samples 605-26-6, 88-91 cm, 613-37-2, 77-80 $\mathrm{cm}, 613-37-4,118-121 \mathrm{~cm}, 613-39-3,119-112 \mathrm{~cm}$, and $613-44-3,117-120 \mathrm{~cm}$, all of which are from intervals visually evaluated as slumped sediments at the time of sampling. Samples 605-29-5, 79-82 cm, 613-36-3, 33-36 $\mathrm{cm}$, and 613-50-3, 87-90 cm do not contain $n$-alkane hydrocarbons in the pyrolyzate. These samples are from sediments visually evaluated as non-slumped. $n$-Alkanes are also present in Sample 605-35-3, 78-81 cm, and heptadecane $\left(n \mathrm{C}_{17}\right)$ was found in $605-31-3,80-83 \mathrm{~cm}, 613-$ $43-3,68-71 \mathrm{~cm}$, and $613-52-3,102-105 \mathrm{~cm}$, although these samples were visually evaluated as non-slumped. The $n$-alkane peaks observed, however, are small when compared with the predominant oxygen- and nitrogencontaining compounds (note in Fig. 2A, for example, the relative size of the heptadecane peak compared with the methylpyridine peak). Because $n$-alkane peaks are not predominant in the chromatograms, these samples more closely resemble non-slumped sediments.

The presence and relative predominance of $n$-alkane hydrocarbons in the pyrolyzate of slumped sediment samples may indicate better preservation of alkyl chains in the sediment organic matter. For colloidal organic matter, the pyrolysis of the fatty acid fraction yields primarily olefins and saturated hydrocarbons (Sigleo et al., 1982). $n$-Alkanes in the pyrolyzate of slumped sediments (or any sediment) probably indicate the preservation of some lipid component in the sediment organic matter.

The presence of moderate bioturbation in slumped sediments, in contrast to intense bioturbation in nonslumped sediments, suggests that the action of bottom- 
Table 3. Compounds found in pyrolysis-GCMS of sediment samples from DSDP Holes 605 and 613 (as identified in preliminary fashion by Finnigan INCOS data system).

\begin{tabular}{|c|c|c|c|}
\hline $\begin{array}{c}\text { Sample } \\
\text { (interval in } \mathrm{cm} \text { ) }\end{array}$ & Nitrogen compounds & $\begin{array}{l}\text { Oxygen-containing } \\
\text { compounds }\end{array}$ & Hydrocarbons \\
\hline $\begin{array}{l}\text { 605-26-6, 88-91 } \\
\text { (slumped) }\end{array}$ & $\begin{array}{l}\text { 3- or } 4 \text {-methylpyridine, } \\
\text { benzopyran? }\end{array}$ & Benzoic acid & $\begin{array}{l}\text { n-Alkanes: nonane, decane, undecane } \\
\text { Branched alkanes: none } \\
\text { Alkenes: 2-ethyl-1-hexene, } \mathrm{C}_{7} \text { alkene } \\
\text { Alkyl and dialkyl aromatics: propyl benzene, } \\
\text { ethyl-methyl-benzene, 1-methyl-ethyl- } \\
\text { benzene, 1-methyl-2-propyl-benzene, } \\
\text { pentyl benzene, } 2 \text {-methyl-napthalene, } \\
\text { 3-methyl-napthalene } \\
\text { Unsubstituted aromatics: naphthalene }\end{array}$ \\
\hline $\begin{array}{l}\text { 605-29-5, 79-82 } \\
\text { (non-slumped) }\end{array}$ & $\begin{array}{l}\text { 4-methylpyridine, }{ }^{*} \text {-ethenyl } \\
\text { pyridine, } n \text {-phenylben- } \\
\text { zenamine, isoquinoline }\end{array}$ & $\begin{array}{l}\text { Benzofuran, 2-methyl } \\
\text { benzofuran }\end{array}$ & $\begin{array}{l}\text { n-Alkanes: none } \\
\text { Branched alkanes: 2,4-dimethyl-undecane } \\
\text { Alkenes: 3,4-dimethyl-1-pentene, } C_{7} \text { alkene, } \\
\text { 4-methyl-1-hexene } \\
\text { Alkyl and dialkyl aromatics: propylbenzene, } \\
\text { 1-ethyl-3-methylbenzene, methylstyrene, } \\
\text { 1-methyl-3-propyl-benzene, } \\
\text { 2-methyl-3-propyl-benzene, 1-methyl- } \\
\text { 4-methylethyl-benzene, 2-methyl naptha- } \\
\text { lene } \\
\text { Unsubstituted aromatics: none }\end{array}$ \\
\hline $\begin{array}{l}\text { 605-31-3, 80-83 } \\
\text { (non-slumped) }\end{array}$ & $\begin{array}{l}\text { 3- or 4-methylpyridine, }{ }^{*} \\
n \text {-phenylbenzenamine, } \\
\text { methanamine, quinoline }\end{array}$ & $\begin{array}{l}\text { 1-phenyl-ethanone, iso- } \\
\text { benzofurandione, 8- } \\
\text { ethyl-3,4-dihydro- } \\
\text { naphthaleneone }\end{array}$ & $\begin{array}{l}\text { n-Alkanes: heptadecane } \\
\text { Branched alkanes: 3,3-dimethylhexane, } \\
\text { 3-methyldodecane, 2,7-dimethyloctane, } \\
\text { 4,7-dimethylundecane, 2,6,10,14-tetra- } \\
\text { methylpentadecane (pristane) } \\
\text { Alkenes: 2-ethyl-1-hexene, 3,4-dimethyl- } \\
\text { 1-pentene } \\
\text { Alkyl and dialkyl aromatics: pentylbenzene, } \\
\text { 2-methylnaphthalene } \\
\text { Unsubstituted aromatics: none }\end{array}$ \\
\hline $\begin{array}{l}\text { 605-35-3, 70-81 } \\
\text { (non-slumped) }\end{array}$ & $\begin{array}{l}\text { 4-methylpyridine, } \\
\qquad \mathrm{C}_{8} \mathrm{H}_{5} \mathrm{O}_{2} \mathrm{~N}, n \text {-phenyl- } \\
\text { benzenamine }\end{array}$ & $\begin{array}{l}\text { Phenol, 3-methyl phenol, } \\
\text { benzoic acid }\end{array}$ & $\begin{array}{l}\text { n-Alkanes, } n \text {-octane, nonane, hexadecane } \\
\text { Branched alkanes: } 2,7 \text {-dimethyloctane, } \\
\text { 2,4-dimethyl-undecane, } 2,6,10,14- \\
\text { tetramethylpentadecane (pristane) } \\
\text { Alkenes: none } \\
\text { Alkyl and dialkyl aromatics: xylene } \\
\text { Unsubstituted aromatics: none }\end{array}$ \\
\hline $\begin{array}{l}\text { 613-36-3, 33-36 } \\
\text { (non-slumped) }\end{array}$ & $n$-phenylbenzenamine & $\begin{array}{l}\text { Phenol, 2,4,6-trimethyl- } \\
\text { 4-heptene-3-one, } \\
\text { 2,4-dimethyl- } \\
\text { 3-hexanone }\end{array}$ & $\begin{array}{l}\text { n-Alkanes: none } \\
\text { Branched alkanes: } 2,7 \text {-dimethyloctane, } \\
\text { 3,3-dimethylhexane } \\
\text { Alkenes: nonene, 4-undecene } \\
\text { Alkyl and dialkyl aromatics: xylene, methyl- } \\
\quad \text { propylbenzene } \\
\text { Unsubstituted aromatics: none }\end{array}$ \\
\hline $\begin{array}{l}\text { 613-37-2, 77-80 } \\
\text { (slumped) }\end{array}$ & $\begin{array}{l}\text { 3- or 4-methylpyridine, } \\
\text { n-phenylbenzenamine }\end{array}$ & $\begin{array}{c}\text { 4-methoxy-4-methyl- } \\
\text { 1, 2-pentadiene }\end{array}$ & $\begin{array}{l}\text { n-Alkanes: heptadecane* } \\
\text { Branched alkanes: } 2,3,4 \text {-trimethylhexane, } \\
\text { 2,7-dimethyl-octane, 2,4-dimethyl- } \\
\text { decane, 2,4,6-trimethyloctane, } \\
\text { 3,5-dimethylundecane, 6-methyl-tridec- } \\
\text { ane; } 2,6,10,14 \text {-tetramethylpentadecane } \\
\text { (pristane) } \\
\text { Alkenes: } C_{7} \text { alkene } \\
\text { Alkyl and dialkyl aromatics: toluene, xylene } \\
\text { Unsubstituted aromatics: none }\end{array}$ \\
\hline $\begin{array}{l}\text { 613-37-4, 118-121 } \\
\text { (slumped) }\end{array}$ & None detected & None detected & $\begin{array}{l}\text { n-Alkanes: nonane, decane, }{ }^{*} \text { undecane* } \\
\text { Branched alkanes: 1-methylethylpentane } \\
\text { Alkenes: } C_{7} \text { alkene, nonene, decene, } \\
\text { undecene, } \\
\text { 3-decene } \\
\text { Alkyl and dialkyl aromatics: propyl-benzene, } \\
\text { 1-ethyl-3-methylbenzene, 1,2,4-trimethyl- } \\
\text { benzene, 1-ethyl-2-methyl-benzene, } \\
\text { 1,3,5-tri-methylbenzene,** } \\
\text { 1,2,3-trimethylbenzene, }{ }^{*} \text { 2-propenyl- } \\
\text { benzene, 1-ethenyl-4-methylbenzene, } \\
\text { 2-methylpropylbenzene, 4-ethenyl- } \\
\text { 1,2-dimethylbenzene, xylene } \\
\text { Unsubstituted aromatics: naphthalene }\end{array}$ \\
\hline $\begin{array}{c}\text { 613-39-3, 119-122 } \\
\text { (slumped) }\end{array}$ & $\begin{array}{l}4 \text { or } 3 \text { methylpyridine, } \\
\text { quinoline, } \mathrm{C}_{6} \mathrm{H}_{6} \mathrm{O}_{2} \mathrm{~N}_{2} \text {, } \\
\text { n-phenylbenzenamine }\end{array}$ & $\begin{array}{l}\text { Phenol, 2-methyl-2-phenyl- } \\
\text { pentadecane, dimethyl } \\
\text { phenol,*1,3-iso-benzo- } \\
\text { furandione, 3-phenyl- } \\
\text { 2-propenal, decalone, } \\
\text { unknown ketone } \\
\text { derivative }\end{array}$ & $\begin{array}{l}\text { n-Alkanes: tetradecane, pentadecane,* } \\
\text { heptadecane* } \\
\text { Branched alkanes: 3-ethyl-2-methylpentane, } \\
\text { octylcyclohexane, methyl-pentylcyclohex- } \\
\text { ane, 2-methylpentadecane, } 2,6,10,14- \\
\text { tetramethylpentadecane (pristane) } \\
\text { Alkenes: } 3,4,4 \text {-trimethyl-2-hexene, } C_{8} \text { alkene } \\
\text { Alkyl and dialkyl aromatics: none } \\
\text { Unsubstituted aromatics: none }\end{array}$ \\
\hline
\end{tabular}


Table 3 (continued).

\begin{tabular}{|c|c|c|c|}
\hline $\begin{array}{c}\text { Sample } \\
\text { (interval in } \mathrm{cm} \text { ) }\end{array}$ & Nitrogen compounds & $\begin{array}{l}\text { Oxygen-containing } \\
\text { compounds }\end{array}$ & Hydrocarbons \\
\hline $\begin{array}{l}\text { 613-43-3, 68-71 } \\
\text { (non-slumped) }\end{array}$ & $\begin{array}{l}\text { Heterocyclic nitrogen } \\
\text { compound, } 4 \text { - or } \\
\text { 3-methylpyridine, } \\
n \text {-phenylbenzenamine }\end{array}$ & Phenol & $\begin{array}{l}\text { n-Alkanes: heptadecane } \\
\text { Branched alkanes: } 2,6,10,14 \text {-tetramethyl- } \\
\quad \text { pentadecane (pristane) } \\
\text { Alkene: } 1 \text {-alkene } \\
\text { Alkyl and dialkyl aromatics: xylene } \\
\text { Unsubstituted aromatics: none }\end{array}$ \\
\hline $\begin{array}{l}613-44-3,117-120 \\
\text { (slumped) }\end{array}$ & $\begin{array}{l}\text { 3- or 4-methylpyridine, } \\
n \text {-phenylbenzenamine }\end{array}$ & Phenol & $\begin{array}{l}\text { n-Alkanes: tetradecane, pentadecane,* } \\
\text { hexadecane,* heptadecane* } \\
\text { Branched alkanes: hexylcyclohexane, } \\
\text { 5-propyldecane, 2,7-dimethylundecane, } \\
\text { 2-ethyltridecane, 2-methylpentadecane, } \\
\text { 2,6,11-trimethyldodecane, }{ }^{*} \text { 4-ethyltetra- } \\
\text { decane, 2,6,10,14-tetramethyl-pentade- } \\
\text { cane (pristane), cycloalkane } \mathrm{C}_{14} \\
\text { Alkenes: unknown alkene, } 2,2 \text {-dimethyl- } \\
\text { decene, heptadecene } \\
\text { Alkyl and dialkyl aromatics: none } \\
\text { Unsubstituted aromatics: none }\end{array}$ \\
\hline $\begin{array}{l}613-50-3,87-90 \\
\text { (non-slumped) }\end{array}$ & $\begin{array}{l}\text { 3- or 4-methylpyridine, }{ }^{*} \\
\text { 5-hydroxypentanamide, } \\
n \text {-phenylbenzenamine, } \\
\text { isoquinoline }\end{array}$ & $\begin{array}{l}\text { Phenol, acetophenone, } \\
\text { pentanal, benzoic acid, } \\
\text { 3-methyl-2-butene- } \\
\text { 2-one, unknown ketone }\end{array}$ & $\begin{array}{l}\text { n-Alkanes: none } \\
\text { Branched alkanes: } 2,4,5 \text {-trimethyloctane, } \\
\text { 2,4-dimethylundecane } \\
\text { Alkenes: unknown alkene } \\
\text { Alkyl and dialkyl aromatics: xylene } \\
\text { Unsubstituted aromatics: napthalene }\end{array}$ \\
\hline $\begin{array}{r}613-52-3,102-105 \\
\text { (non-slumped) }\end{array}$ & $\begin{array}{l}\text { 3-methylpyridine, 5-hy- } \\
\text { droxypentanamide, } \\
\text { quinoline }\end{array}$ & $\begin{array}{l}\text { 3-methyl-pentanal, 2-pentyl } \\
\text { furan, 3-hydroxy- } \\
\text { 3-methyl-2-butanone, } \\
\text { 2,4-dimethyl-3-hex- } \\
\text { anone, unknown } \\
\text { ketone }\end{array}$ & $\begin{array}{l}\text { n-Alkanes: heptadecane } \\
\text { Branched alkanes: 1,1,3-trimethylcyclopen- } \\
\quad \text { tane, 2,6,10,14-tetramethylpentadecane } \\
\quad \text { (pristane), 2,4-dimethylundecane } \\
\text { Alkenes: none } \\
\text { Alkyl and dialkyl aromatics: none } \\
\text { Unsubstituted aromatics: none }\end{array}$ \\
\hline
\end{tabular}

*Dominant peaks in the chromatogram.

dwelling organisms may be responsible for the observed differences in the $n$-alkane fraction of the pyrolyzate. Differences in the degree of bioturbation could account for differences in the preservation of lipid components in the sediment organic matter. Because some lipid compounds show a rapid turnover rate in surface sediments (Farrington et al., 1977; Volkman et al., 1983), it also seems likely that these labile compounds could readily reflect changes in biodegradation rates when these sediments were at the surface during the middle and early Eocene. The presence of $n$-alkanes in the pyrolyzate of slumped sediments suggests more moderate biodegradation by the bottom-dwelling fauna at the original site of deposition. During the slumping event, the sediments moved downslope as an intact block, which protected the sediments from a second cycle of bioturbation by essentially "burying" some of the sediments out of the reach of the bottom-dwelling organisms at the site of relocation. Alternatively, $n$-alkanes in the pyrolyzate of slumped sediments could indicate a different source of organic input.

No obvious qualitative differences were found between branched alkanes and $n$-alkenes of slumped and nonslumped sediments (see Table 3). For example, several branched alkanes are present in Samples 613-37-2, 77$80 \mathrm{~cm}$ and $605-31-3,65-68 \mathrm{~cm}$, from intervals described as slumped and non-slumped sediment, respectively. No branched alkanes are present in Sample 605-26-6, 88-91 $\mathrm{cm}$, which is from a slumped interval. Alkenes are present in both slumped and non-slumped sediments, as are unsubstituted aromatic hydrocarbons. Sample 613-37-4, $118-121 \mathrm{~cm}$, a slumped sediment, does have some domi- nant $n$-alkene hydrocarbons, and they appear associated with the $n$-alkanes as $n$-alkane/ $n$-alkene pairs.

Several alkyl and dialkyl aromatics are present in Samples 605-26-6, 88-91 cm and 613-37-4, 118-121 cm, which were described as slumped sediments and which contain $n$-alkanes in the pyrolyzate. Several alkyl and dialkyl aromatics are also present in Sample 605-29-5, 79-82 cm, which was described to be a non-slumped sediment and which does not contain $n$-alkanes in the pyrolyzate (Table 3). It is suggested that the presence of these alkyl and dialkyl aromatics, in contrast to the $n$-alkane hydrocarbons, may be related to the source rather than to the depositional history of the organic matter. A qualitative comparison of pyrolysis-GCMS studies of DSDP Leg 96 sediments (the Mississippi Fan) shows that alkyl and dialkyl aromatics appear to predominate over $n$-alkane/ $n$-alkene homologous hydrocarbons when the sediments have a terrigenous source instead of a marine source (Whelan, unpublished data). Macroscopic and microscopic examination of the Eocene sediments at Sites 605 and 613 revealed no significant terrigenous component (Poag, Watts, et al., this volume). Because both sites are located on the continental rise, however, it is reasonable to expect that some of these sediments may have received a terrigenous input. More intense reworking by bottom-dwelling organisms, slower depositional rates, and lower percentages of organic carbon, compared with Leg 96 (Mississippi Fan) sediments, characterize Site 605 and 613 sediments. This results in generally lower levels of pyrolyzable organic matter in these sediments, making it more difficult to ascertain a source for these compounds. 


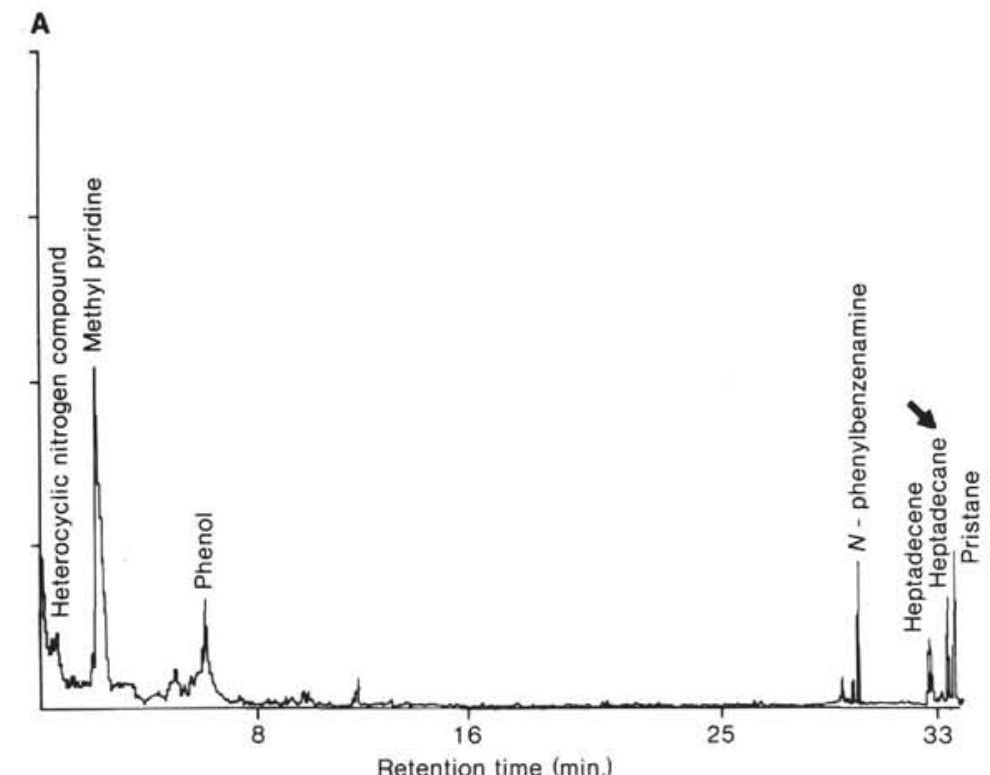

B

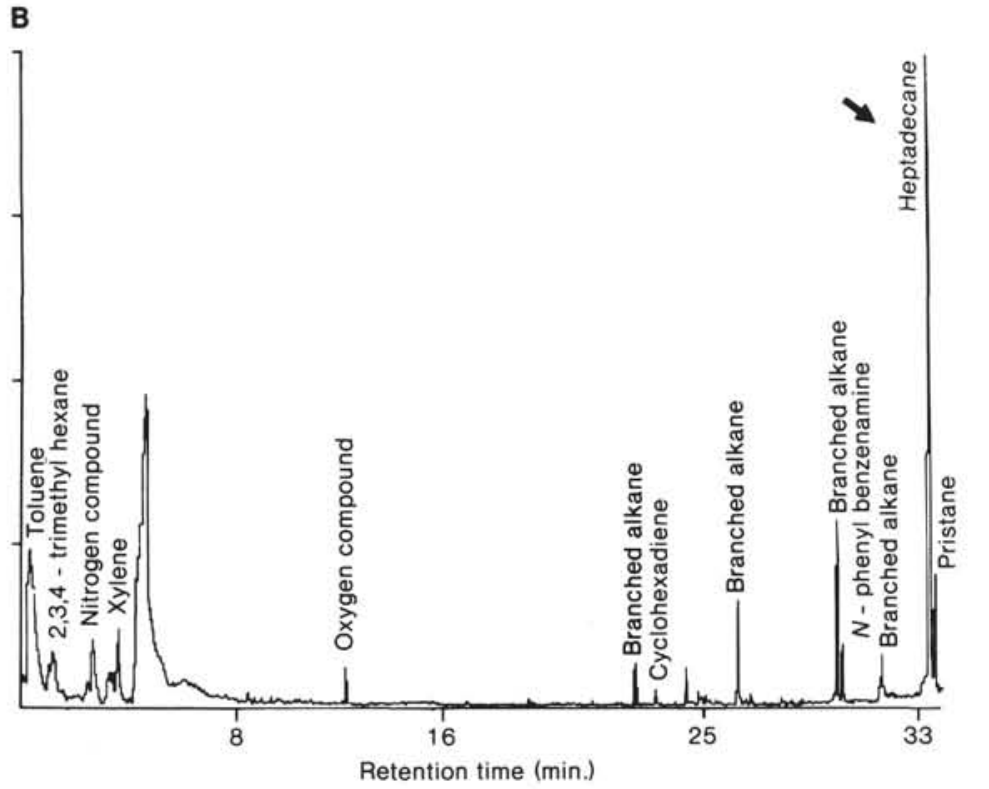

C

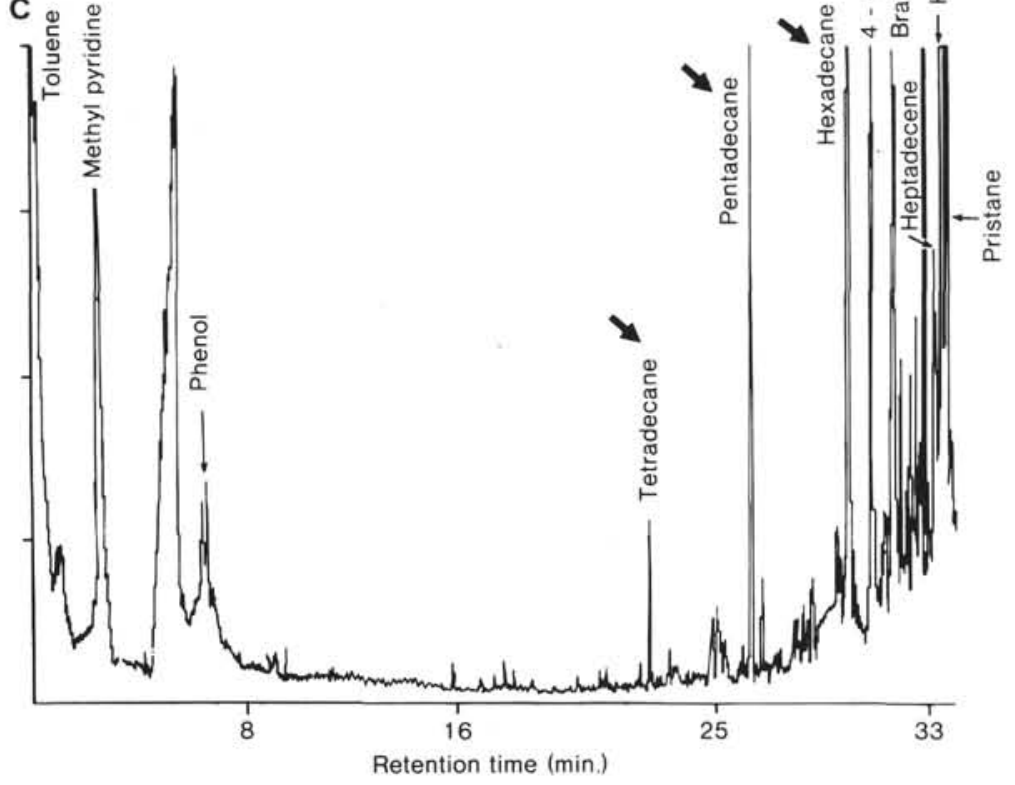

Figure 2. Reconstructed ion chromatograms obtained from GCMS analysis of pyrolysis products. A. Sample 613-43-3, 68-71 cm. This sample was recognized visually to be a non-slumped sediment. Note the weak signal for heptadecane (arrow). B. Sample $613-37-2,77-80 \mathrm{~cm}$. This sample was recognized by visual examination of the core to be a slumped sediment. Even though this chromatogram is weaker than those obtained for other slumps in this study, note the predominance of heptadecane. C. Sample 613-44$3,117-120 \mathrm{~cm}$. This sample was also recognized by visual examination of the core to be a slumped sediment. Note the presence of $\mathrm{C}_{15}-\mathrm{C}_{17} n$-alkanes (arrows). 


\section{Percent Organic Carbon}

The presence of $n$-alkanes in slumped sediments, and their nearly complete absence in non-slumped sediments, suggest a difference in the degree of preservation of organic matter in middle and lower Eocene sediments. These differences in preservation might be reflected either in the percent organic carbon of the sediments or in the total yields of pyrolyzable organic matter. Tables 1 and 2 show that organic carbon percentages for these samples range between 0.24 and $0.50 \%$. The mean and standard deviation for percent organic carbon is $0.32 \pm 0.07$ and $0.38 \pm 0.09$ for non-slumped and slumped sediments, respectively, indicating that the percentages of organic carbon in these sediments are similar.

\section{Pyrolysis-GC}

Pyrolysis-GC was used to determine whether differences in the amounts of total pyrolyzable organic matter could be found in the sediments. Figures 3 and 4 are plots of total FID integrator response for the gas chromatogram of the pyrolysis products, normalized to gram organic carbon of the sample. The error bars in the figures were obtained from two or more replicate runs. For Figures 3 and 4, higher integrator counts correspond to higher amounts of compounds generated from pyrolysis and lower counts correspond to lower amounts. If an average response factor of normal saturated hydrocarbons $\left(n \mathrm{C}_{7}\right.$ to $\left.n \mathrm{C}_{18}\right)$ is used to normalize this data, Sample 613-39-3, 119-122 cm, which is a "midway" point in Figure 4, yields approximately $60 \mathrm{mg}$ of hydrocarbon per gram of organic carbon (also known as the hydrogen index; Espitalié et al., 1977). Mukhopadhyay et al. (1985) summarized this value for some known petroleum source rocks. The values ranged between 73 and $942 \mathrm{mg}$ $\mathrm{HC} / \mathrm{g} \mathrm{C}_{\mathrm{org}}$, with most of the values (27 out of 35 ) falling between 250 and $700 \mathrm{mg} \mathrm{HC} / \mathrm{g} \mathrm{C}_{\text {org }}$.

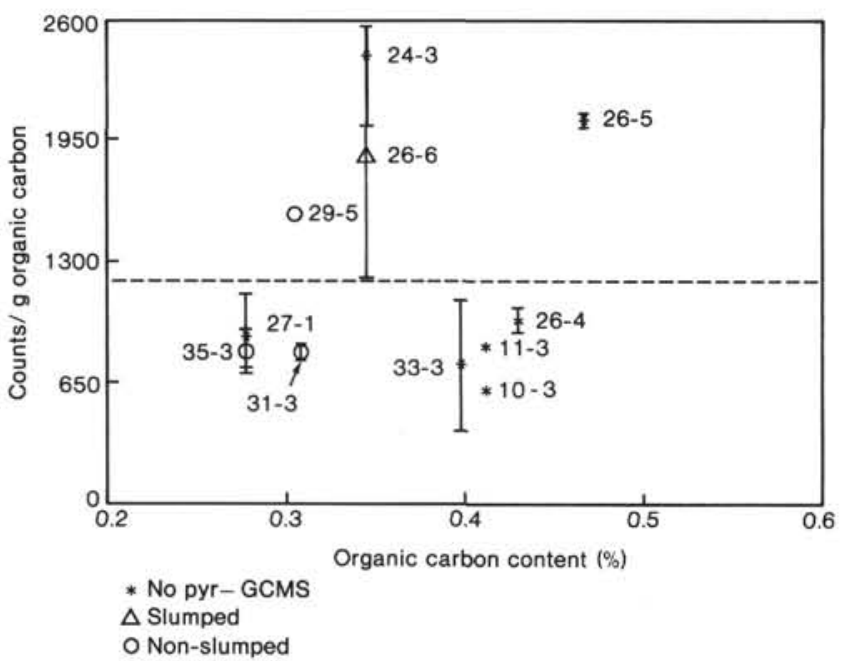

Figure 3. FID response (counts/gram organic carbon) vs. percent organic carbon for DSDP Hole 605. The three sample categories noted in the legend are described in detail in the discussion of pyrolysisGC; lines through the points are error bars ( $1 \sigma$ standard deviations). See Table 1 for sample $\mathrm{cm}$ intervals.

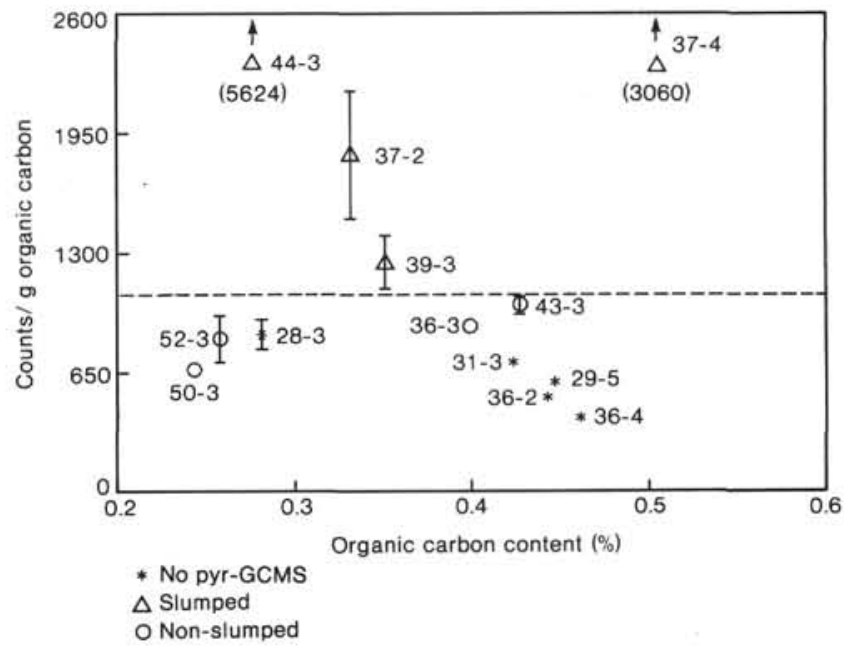

Figure 4. FID response (counts/gram organic carbon) vs. percent organic carbon for DSDP Hole 613. The three sample categories noted in the legend are described in detail in the discussion of pyrolysisGC; lines through the points are error bars ( $1 \sigma$ standard deviations). See Table 2 for sample $\mathrm{cm}$ intervals.

To test the hypothesis that slumped and non-slumped sediments exhibit quantitative differences in the amounts of pyrolyzable organic matter, samples plotted for each hole (Figs. 3 and 4) are arranged into three groups: (1) "unknowns" for which no pyrolysis-GCMS analysis was done and for which depositional history was uncertain from visual inspection of the cores; and samples that, from pyrolysis-GCMS analysis and examination of the cores, are (2) slumped sediment or (3) non-slumped sediment.

In Figure 3, the four samples from Hole 605 with the highest yields of pyrolyzable organic matter are Samples 605-24-3, 114-117 cm, 605-26-5, 118-121 cm, 605-26-6, $88-91 \mathrm{~cm}$, and 605-29-5, 79-82 cm. Sample 605-26-6, $88-91 \mathrm{~cm}$ was one of the samples described as a slumped sediment, and Sample 605-29-5, 79-82 cm was described as a non-slumped sediment. Sample 605-24-3, 114-117 $\mathrm{cm}$ is an "unknown" because no pyrolysis-GCMS analysis was done on the sample and because it is from an interval for which the depositional history was uncertain. Sample $605-26-5,118-121 \mathrm{~cm}$ is plotted as an "unknown" because of no pyrolysis-GCMS data, although it is from an interval visually evaluated as a slumped sediment. The highest yields of pyrolyzable organic matter for Hole 613 were obtained from sediment Samples $613-37-4,118-121 \mathrm{~cm}$ and $613-44-3,117-120 \mathrm{~cm}$, which are points off-scale on Figure 4, and Samples 613-37-2, $77-80 \mathrm{~cm}$ and $613-39-3,119-122 \mathrm{~cm}$. These four samples were described as slumped sediments. Dotted lines drawn through Figures 3 and 4 are reference lines to separate these "high-end" members from the rest of the samples. Note that the dotted lines are drawn at approximately the same height through each of the two figures (corresponding to approximately the same counts/gram organic carbon), the dotted line through Figure 3 (Hole 605 ) being slightly higher.

In Figures 3 and 4 all of the "slumps" plot above the dotted line. All of the "non-slumped sediments" plot be- 
low the dotted line, except Sample 605-29-5, 79-82 cm in Figure 3, which plots above the line. Sample 605-29-5, $79-82 \mathrm{~cm}$ is one of the three samples in which several al$\mathrm{kyl}$ and dialkyl aromatics were found in the pyrolyzate. As suggested earlier, this may indicate a different source of organic input for this sample, possibly material not so easily degradable as that in the rest of the samples.

Excluding results from Sample 605-29-5, 79-82 cm, the data plotted in Figures 3 and 4 indicate that total yields of pyrolyzable organic matter are higher in slumped sediments than in non-slumped sediments. In contrast, measurements of percent organic carbon show no differences. "Bulk" measurements of organic carbon measure the total amount (refractory and labile) of organic carbon in the sediment. Pyrolysis techniques measure the amount of pyrolyzable organic material, which is the more labile component of the sediment organic matter. Measurements of the more labile fraction of the organic matter may provide better detection of differences in preservation and biodegradation. Results from pyrolysis-GCMS show that alkyl side-chains, which probably indicate labile lipid components in the sediment organic matter, are better preserved in the slumped sediments. Higher yields of pyrolyzable organic matter, shown quantitatively by pyrolysis-GC, and the preservation of alkyl chains in the sediment organic matter, as evident qualitatively from the $n$-alkanes found from pyrolysis-GCMS, indicate better preservation of the sediment organic matter in the slumped sediments. As mentioned earlier, this could be due to less biodegradation at the original deposition site of the slumped sediments or, alternatively, a difference source of organic input. Because bioturbation was noted visually to be more moderate in the sediment slumps, the former seems a more likely explanation for the observed results. Assuming that the organic input was the same, it is also possible, however, that the observed results may reflect differences (such as sinking and transport times) in the original conditions of deposition before the slumping event.

With these results in mind, it is interesting to postulate the depositional history of the "unknowns" in Figures 3 and 4 and Tables 1 and 2 . The data suggest that Samples 605-10-3, 7-10 cm, 605-11-3, 43-46 cm, $605-26-4,115-118 \mathrm{~cm}$, and 605-27-1, 10-13 cm (Fig. 3) and 613-28-3, 70-73 cm, 613-29-5, 83-85 cm, 613-31-3, 65-68 cm, 613-36-2, 93-96 cm, and 613-36-4, 70-73 cm (Fig. 4) are not slumped sediments. All of these samples fall below the dotted lines and have low yields of total pyrolyzable organic matter, indicating that the organic material in these sediments has been more reworked. Samples 605-24-3, 114-117 cm and 605-26-5, 118-121 cm (Fig. 3) may be slumped sediments, on the basis of the higher yields of pyrolyzable organic matter. From these data alone, however, an estimate of depositional history cannot be made, because possible changes in the type of organic matter, as shown by the presence of alkyl and dialkyl aromatics in Sample 605-29-5, 79-82 cm (Fig. 3) can result in erroneous conclusions. Qualitative comparison of types of organic matter by pyrolysis-GC or by pyrolysis-GCMS is vital to the interpretation of these data.

\section{CONCLUSIONS}

1. Sediment slumps in the middle and lower Eocene sediments of DSDP Holes 605 and 613 appear to show better preservation of the alkyl side-chain components of the sediment organic matter. This is evident from GCMS studies, which show $n$-alkane hydrocarbons as dominant compounds in the pyrolyzate of samples from these sediments. These $n$-alkanes may reflect the preservation of lipid components in the sediment organic matter.

2. Increases in alkyl and dialkyl aromatics may indicate a different source of organic input, possibly terrigenous, to some of these samples.

3. The percent organic carbon composition for all the samples examined here is generally low.

4. Total pyrolyzable organic matter, as determined by pyrolysis-GC, is generally higher for slumped sediments than for non-slumped sediments.

5. Studies using pyrolysis-GC and pyrolysis-GCMS indicate that the organic matter is better preserved in slumped sediments than in non-slumped sediments. This probably results from a lesser degree of biodegradation at the original site of deposition of the slumped blocks. It is likely that the slumping event protected the sediment from a second cycle of bioturbation. The slumped sediment moved as an intact block which "buried" most of the sediment, shielding it from the action of bottomdwelling organisms at the site of relocation.

6. Pyrolysis techniques provide a clue to the depositional history of sediments. The data obtained from sediment pyrolysis suggest the depositional history of samples recovered from core intervals for which the depositional history was uncertain.

\section{ACKNOWLEDGMENTS}

We would like to acknowledge Christine Burton and Joan Brazier for the organic carbon analysis. Special thanks to Dr. Nelson Frew for the use of and assistance with the GCMS system, and to John P. Jasper for valuable comments on this manuscript. This work was supported by NSF Grant OCE83-00485. WHOI Contribution No. 5983.

\section{REFERENCES}

Espitalié, J., Laporte, J. L., Madec, M., Marquis, F., Leplat, P., et al., 1977. Méthode rapide de caractérisation des roches mères, de leur potentiel pétrolier et de leur degré dévolution. Rev. Inst. Fr. Pet., 32:23-47.

Farrington, J. W., Henrichs, S. M., and Anderson, R., 1977. Fatty acids and $\mathrm{Pb}-210$ geochronology of a sediment core from Buzzards Bay, Massachusetts. Geochim. Cosmochim. Acta, 41:289-296.

Huc, A. Y., Hunt, J. M., and Whelan, J. K., 1981. The organic matter of a Gulf Coast well studied by a thermal analysis-gas chromatography technique. J. Geochem. Explor., 15:671-681.

Jasper, J. P., Whelan, J. K., and Hunt, J. M., 1984. Migration of $C_{1}$ to $\mathrm{C}_{8}$ volatile organic compounds in sediments from the Deep Sea Drilling Project, Leg 75, Hole 530A. In Hay, W. W., Sibuet, J.-C., et al., Init. Repts. DSDP, 75, Pt. 2: Washington (U.S. Govt. Printing Office), 1001-1008.

Mukhopadhyay, P. K., Hagemann, H. W., and Gormly, J. R., 1985. Characterization of kerogens as seen under the aspect of maturation and hydrocarbon generation. Erdol Kohle, 38:7-18. 
Sigleo, A. C., Hoering, T. C., and Helz, G. R., 1982. Composition of estuarine colloidal material: Organic components. Geochim. Cosmochim. Acta, 46:1619-1626.

Volkman, J. K., Farrington, J. W., Gagosian, R. B., and Wakeham, S. G., 1983. Lipid composition of coastal marine sediments from the Peru Upwelling Region. In Bjoroy, M. (Ed.), Advances in Organic Geochemistry: New York (J. Wiley \& Sons), pp. 228-240.
Whelan, J. K., and Hunt, J. M., 1983. Organic matter in DSDP Site 504 and 505 sediments studied by a thermal analysis-gas chromatography technique. In Cann, J. R., Langseth, M. G., Honnorez, J., Von Herzen, R. P., White, S. M., et al., Init. Repts. DSDP, 69: Washington (U.S. Govt. Printing Office), 443-450.

Date of Initial Receipt: 11 April 1985

Date of Acceptance: 11 October 1985 